\title{
Pengembangan Model Pembelajaran Manajemen Bencana Alam Banjir Untuk Anak Usia 4-5 Tahun
}

\author{
Yanti \\ Balai Pengembangan Pendidikan Anak Usia Dini dan Pendidikan Masyarakat \\ Email:dra_hj.yanti62@yahoo.co.id
}

\begin{abstract}
Abstrak
Latar belakang pengembangan model pembelajaran manajemen bencana alam banjir untuk anak usia 4-5 tahun antara lain: 1) Indonesia merupakan negara yang rawan bencana alam. Provinsi riau adalah salah satu bagian dari Indonesia yang juga rawan terkena bencana alam. 2) Salah satu bencana alam yang sering terjadi adalah bencana Hydro-meteorologi. Badan Penanggulangan Bencana Daerah (BPBD) Provinsi Riau (2016) menyatakan ribuan rumah di Kabupaten Kampar tergenang banjir akibat meluapnya Sungai Kampar setelah pembukaan pintu waduk PLTA Koto Panjang. Bencana hidrometeorologi meliputi aspek cuaca, iklim dan perubahan iklim. yang termasuk ke dalam bencana hidrometeorologi yaitu banjir, kekeringan, angin. 3) Berdasarkan hasil observasi dan wawacara tim pengembang pada saat studi eksplorasi di PAUD Kabupaten Kampar, ditemukan bahwa banjir sampai ke dalam ruangan belajar anak, Anak Usia dini memang dalam kondisi yang belum siap dalam menghadapi banjir. Sehingga ada anak yang hanyut ketika banjir dan tidak sedikit pula anak yang menderita penyakit kulit atau kudisan. Tujuan dikembangkan model ini adalah untuk 1) menyusun Pembelajaran manajemen bencana alam banjir untuk anak usia 4-5 tahun, 2) menyusun panduan rancangan pembelajaran manajemen bencana alam banjir untuk anak usia 4-5 tahun, 3) menyusun media pembelajaran manajemen bencana alam banjir untuk anak usia 4-5 tahun menggunakan buku cerita dan lembar kerja anak, dan 4) menyusun panduan penggunaan media pembelajaran manajemen bencana alam banjir untuk anak usia 4-5 tahun. Metode yang dipergunakan yang dipergunakan dalam proses pengembangan model ini adalah Research and Development dengan langkah-langkah dan tahapannya. Teknik pengumpulan data yang dipergunakan antara lain: wawancara, angket, observasi, dan Focus Group Discussion. Sedangkan analisis data yang dipergunakan adalah analisis deskripstif kualitatif untuk menjelaskan hasil studi lapangan, FGD, dan ujicoba penyelenggaraan pembelajaran, serta analisis deskriptif
\end{abstract}


kuantitatif untuk menjelaskan hasil validasi naskah. Hasil validasi naskah Model dan Panduan Pembelajaran manajemen bencana alam banjir untuk anak usia 4-5 tahun termasuk dalam kategori sangat sesuai. Sedangkan hasil ujicoba penyelenggaraan Pembelajaran manajemen bencana alam banjir untuk anak usia 4-5 tahun dapat dilihat pada pencapaian hasil belajar peserta didik. Berdasarkan hasil penilaian, secara keseluruhan dapat disimpulkan tingkat pemahaman peserta didik meningkat setelah mengikuti pembelajaran. Simpulan hasil pengembangan model pembelajaran manajemen bencana alam banjir untuk anak usia 4-5 tahun adalah sebagai berikut: 1) tersusunnya naskah model dan panduan yang telah divalidasi, 2) tersusunnya perencanaan pembelajaran manajemen bencana alam banjir untuk anak usia 4-5 tahun , 3) melaksanakan Pembelajaran manajemen bencana alam untuk anak usia 4-5 tahun , dan 4) menilai tingkat percapaian peserta didik mengenai manajemen bencana alam banjir yang mencakup perkembangan fisik motorik, Bahasa, Kognitif, Nilai Agama dan Moral, Sosial emosional dan seni.

Kata Kunci: Mitigasi Bencana Alam, Anak Usia Dini

\section{PENDAHULUAN}

Menurut Ibnu Rusydy (2016) gambaran grafik sebaran bencana alam di Indonesia tahun 2015. Hal ini menandakan bahwa semua pihak harus mempersiapkan diri. Tidak terkecuali anak usia dini. Senada dengan pendapat Sriwahyuni, S., \& Efastri, S. M. (2017)) bahwa anak usia dini memerlukan perhatian khusus ketika terjadi bencana alam. Salah satu bencana alam yang sering terjadi adalah bencana Hydrometeorologi. Badan Penanggulangan Bencana Daerah (BPBD) Provinsi Riau (2016) menyatakan ribuan rumah di Kabupaten Kampar tergenang banjir akibat meluapnya Sungai Kampar setelah pembukaan pintu waduk PLTA Koto Panjang.
Bencana hidrometeorologi meliputi aspek cuaca, iklim dan perubahan iklim. yang termasuk ke dalam bencana hidrometeorologi yaitu banjir, kekeringan, angin.

Bencana alam khususnya banjir sangat berdampak pada kehidupan fisik dan psikis anak usia dini. Secara fisik, banjir mengakibatkan menurunnya kesehatan anak selanjutnya secara psikis bisa mengakibatkan trauma. Trauma yang timbul dapat merubah perilaku seseorang yang telah mengalami peristiwa traumatis. Khususnya pada anak-anak kejadian peristiwa traumatis dapat merubah perilaku bahkan dapat menghambat perkembangan baik dalam kehidupan sosial, akademis dan psikologisnya. 
Berdasarkan hasil observasi dan wawacara tim pengembang pada saat studi eksplorasi di PAUD Kabupaten Kampar, ditemukan bahwa banjir sampai ke dalam ruangan belajar anak, Anak Usia dini memang dalam kondisi yang belum siap dalam menghadapi banjir. Sehingga ada anak yang hanyut ketika banjir dan tidak sedikit pula anak yang menderita penyakit kulit atau kudisan.

Selanjutnyaa guru belum ada mengenalkan kepada anak mengenai bencana alam, apa dampak dan cara menghadapinya. Hal tersebut terlihat ketika ditanya, apa yang anak didik lakukan pada saat banjir, rata-rata guru menyuruh anak pulang dan meliburkan sekolah.

Hal lain yang terlihat adalah struktur bangunan PAUD yang membuat rawan terkena banjir. Kemudian belum tampak ada perlengkapan keamanan apabila terjadi bencana seperti pelampung, titik kumpul, dan sebagainya.

Pada Kabupaten Kampar yang rentan terkena bencana banjir ini, perlu dikembangkan model pembelajaran manajemen bencana alam agar anak usia dini sudah memahami arti bencana serta bisa melakukan tindakan saat terjadi bencana karena sudah di bekali pengetahuan tentang bencana sehingga bisa mengurangi dampak terjadinya bencana. Selain itu, salah satu langkah awal dalam membangun masyarakat sadar bencana, sehingga saat terjadi bencana mereka tidak panik dan bingung karena sudah memiliki bekal dalam menghadapi bencana, hal ini juga merupakan cara mengurangi risiko bencana. Dengan harapan pengetahuan yang didapat ditularkan pada lingkungan sekitar dalam rangka mengurangi risiko bencana

Berdasarkan uraian di atas maka pada kesempatan ini Tim Pengembang merasa penting untuk melakukan penelitian mengenai Pengembangan Model Pembelajaran Manajemen Bencana pada Anak Usia Dini.

Di tingkat lapangan, dalam proses pembelajaran adanya model yang dapat memberikan panduan bagi pendidik dalam hal manajemen bencana alam seperti banjir. maka Balai Pengembangan Pendidikan Non Formal dan Informal (BPPNFI) akan mengembangkan Model Pembelajaran manajemen bencana alam pada anak usia dini.

\section{METODE}

Proses pengembangan model pembelajaran manajemen bencana alam banjir untuk anak usia 4-5 tahun menggunakan pendekatan Research and Development. Pendekatan ini dipilih karena melalui berbagai tahapan yang dirancang untuk menghasilkan model dan produk yang menyertainya, yaitu buku cerita dan 
lembar kerja anak. Adapun langkahlangkah dalam penelitian dan pengembangan

Populasi dan sampel yang menjadi responden dalam proses pengembangan model ini dapat diuraikan sebagai berikut:

1. Populasi dan sampel studi lapangan

Responden studi lapangan berjumlah 80 orang berasal dari 4 lokasi PAUD sebagai berikut: TK Mutiara Bunda (20 orang), PAUD EPTA PANDAU (20 orang), TK Aisyiyah Bustanul Athfal 3 peserta (20 orang), dan TK Taruna Cempaka peserta (20 orang).

2. Populasi dan sampel FGD desain model

Responden kegiatan FGD desain model berjumlah 15 orang, dengan unsur sebagai berikut: Guru 1 orang), Narasumber Teknis (1 orang), Akademisi (1 orang), Praktisi (1 orang), Birokrasi (1 orang), HIMPAUDI (1 orang), Forum PAUD (1 orang), dan Pengelola 1 (1 orang) dan pembahas 6 (6 orang).

3. Populasi dan sampel validasi naskah model

Total subjek penelitian Responden kegiatan validasi naskah model berjumlah 36 orang, dengan unsur sebagai berikut: Akademis (1 orang)

Konsultan Teknis (1 orang) Pengelola (2 orang) Guru (12 orang) Dinas Pendidikan (1 orang) Himpaudi (1 orang) Forum PAUD (1 orang) Praktisi (7 orang) dan Pamong Belajar (10 orang).

4. Populasi dan sampel ujicoba penyelenggaraan

Responden ujicoba penyelenggaraan model berjumlah 80 orang yang terdiri atas 4 PAUD yang tersebar pada 4 desa di antaranya TK Mutiara Bunda, PAUD EPTA PANDAU, TK Aisyiyah Bustanul Athfal 3, dan TK Aisyiyah Bustanul Athfal 3, Kabupaten Kampar dengan masing-masing subyek pengembangan yaitu 20 orang setiap lembaga.

1. Lokasi studi lapangan/eksplorasi: TK Mutiara Bunda bulan Juli 2017

2. Lokasi dan waktu validasi naskah model
a. Lokasi : TK Mutiara Bunda
b. Waktu : 23 s.d 25

Oktober 2017

3. Lokasi dan waktu ujicoba penyelenggaran model a. PAUD EPTA Pandau 
b. TK Aisyiyah Bustanul Athfal 3

c. TK Taruna Cempaka

Waktu pelaksanaan ujicoba operasional/penyelenggaraan model adalah pada 20 s.d 25 November 2017, dan 27-29 November 2017

Prosedur pengembangan model pembelajaran manajemen bencana alam banjir untuk anak usia 4-5 tahun adalah:

1. Studi lapangan, yang dilaksanakan untuk memperoleh informasi dari Guru mengenai pemahaman dan pelaksanaan pembelajaran manajemen bencana alam banjir.

2. Focus Group Discussion (FGD), yang dilaksanakan untuk merumuskan bentuk model, panduan, dan bahan belajar baik substansi maupun redaksinya.

3. Penyusunan desain pengembangan oleh tim pengembang untuk menggambarkan bentuk dan proses yang akan dilakukan.

4. Penyusunan rancangan ujicoba untuk memberikan gambaran proses ujicoba yang akan dilaksanakan.

5. Pelaksanaan ujicoba naskah untuk memperoleh masukan dan koreksi dari responden baik redaksi maupun substansi naskah model.
6. Pelaksanaan ujicoba penyelenggaraan dengan melibatkan Guru sebagai pelaksana proses pembelajaran.

7. Evaluasi hasil ujicoba dilakukan untuk menilai Pembelajaran manajemen bencana alam untuk anak usia 4-5 tahun pada peserta didik

$\begin{array}{ccc}\begin{array}{c}\text { Analisis data } \\ \text { pengembangan }\end{array} & \text { dalam } \\ \text { model }\end{array}$
pembelajaran manajemen bencana alam banjir untuk anak usia 4-5 tahun terbagi atas:

1. Analisis deskripstif kualitatif untuk menjelaskan hasil studi lapangan, FGD, dan ujicoba penyelenggaraan pembelajaran

2. Analisis deskriptif kuantitatif untuk menjelaskan hasil validasi naskah

3. Analisis hasil uji coba konseptual dan operasional model dengan menggunakan rumus persentase/meanrata-rata. $\mathrm{P}=\mathrm{F} / \mathrm{N} X 100 \%$.

\section{HASIL DAN PEMBAHASAN Hasil Penelitian}

Gambaran umum naskah Model Pembelajaran manajemen bencana alam banjir untuk anak usia 4-5 tahun, dapat diuraikan secara singkat mengenai model dan produk yang menyertainya, sebagai berikut: 
1. Deskripsi Model pembelajaran manajemen bencana alam banjir untuk anak usia 4-5 tahun

2. Deskripsi Panduan Penilaian Pembelajaran manajemen bencana alam untuk anak usia 4-5 tahun Pada Peserta didik

Penilaian dilakukan secara konsisten, sistematik dan terprogram dengan menggunakan tes dalam bentuk tertulis atau lisan dan nontes dalam bentuk pengamatan kerja, pengukuran sikap, penilaian hasil karya, proyek/ produk, portofolio dan penilaian diri. Penilaian hasil belajar untuk memperoleh ijazah program paket dilakukan setelah peserta didik mencapai perkembangannya.

Berikut instrumen pengembangan model pembelajaran manajemen bencana alam banjir untuk anak usia 4-5 tahun

3. Deskripsi Panduan media Pembelajaran manajemen bencana alam banjir untuk anak usia 4-5 tahun terdapat pada panduan terlampir

\section{A. Hasil Uji Konseptual}

Uji coba konseptual dilakukan pada TK Mutiara Bunda pada tanggal 23-25 Oktober 2017, berdasarkan pengolahan data instrument, maka diperoleh hasil:

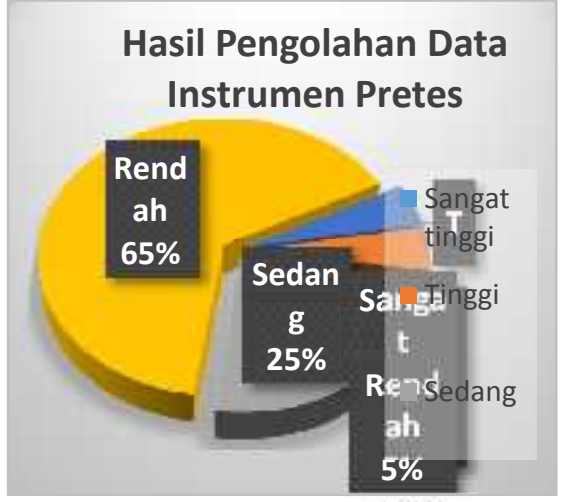

Sebelum dilaksanakan pembelajaran manajemen bencana alam banjir, anak usia dini mengisi questioner terlebih dahulu untuk mengukur tingkat pemahaman dan kompetensi anak usia dini dalam manajemen banjir. Adapun hasil yang diperoleh adalah $65 \%$ dari keseluruhan anak memiliki tingkat pemahaman dan yang rendah. 25 \% lainnya berada pada kategori sedang, $5 \%$ anak berada pada kategori sangat rendah.

Berdasarkan hasil pretest dapat disimpulkan bahwa rata-rata anak usia dini perlu mengikuti pembelajaran manajemen bencana alam banjir. 


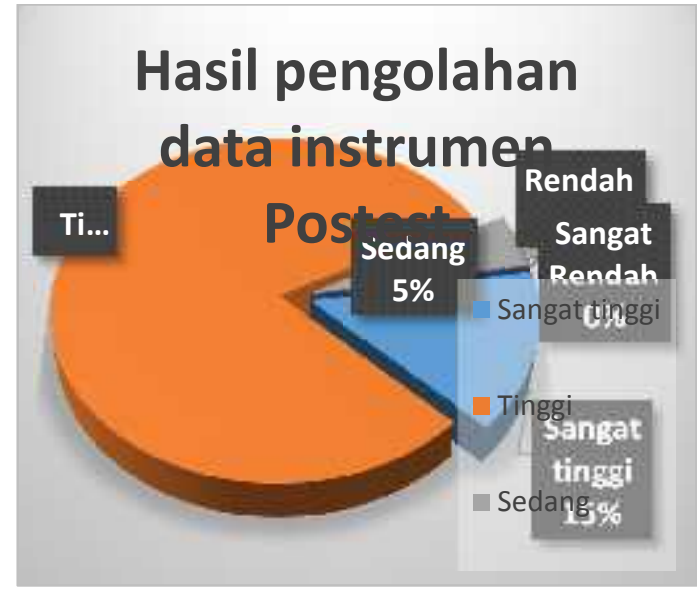

Setelah pelaksanaan pembelajaran maka diperoleh hasil yang memuaskan. Hal ini ditunjukkan dari hasil postest yang menunjukkan bahwa $80 \%$ anak usia 4-5 tahun memiliki kemampuan dan pemahaman yang tinggi dalam manajemen bencana alam banjir. Hanya $5 \%$ diantaranya yang masih berada pada kategori sedang. Untuk melihat perbandingan hasil pretes dan postest silahkan lihat grafik berikut:

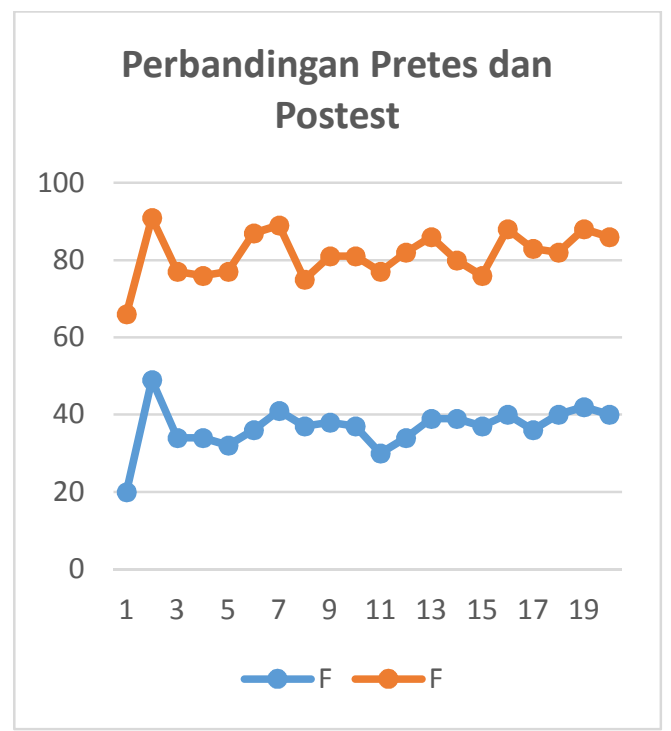

Dari hasil analisis data, maka disimpulkan bahwa terdapat perubahan dan peningkatan secara signifikan pemahaman anak usia dini sebelum dan sesudah dilaksanakannya model. Berdasarkan grafik di atas, semua indicator/materi pembelajaran meningkat dari sebelum pemberian perlakuan sampai dengan setelah pelaksanaan pembelajaran manajemen bencana banjir.

\section{B. Hasil Uji Operasional}

Hasil uji coba operasional didapatkan melalui questioner yang diisi oleh anak dijabarkan sebagai berikut:

\section{PAUD EPTA Pandau}

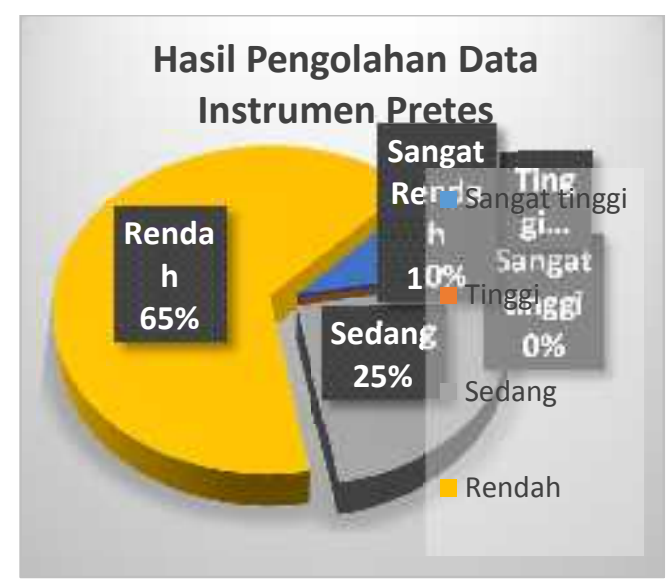

Sebelum dilaksanakan pembelajaran, anak usia 4-5 tahun mengisi questioner terlebih dahulu melalui wawancara oleh guru untuk mengukur tingkat pemahaman dan kompetensi anak usia 4-5 tahun dalam manajemen bencana alam banjir. Adapun hasil yang diperoleh adalah $65 \%$ dari keseluruhan anak memiliki tingkat pemahaman mengenai bencana alam banjir adalah 
rendah. $25 \%$ lainnya berada pada kategori sedang, $10 \%$ anak berada pada kategori sangat rendah, dan hanya tidak anak yang berada pada kategori tinggi dan sangat tinggi.

Berdasarkan hasil pretest dapat disimpulkan bahwa rata-rata anak perlu mengikuti pembelajaran manajemen bencana alam banjir.

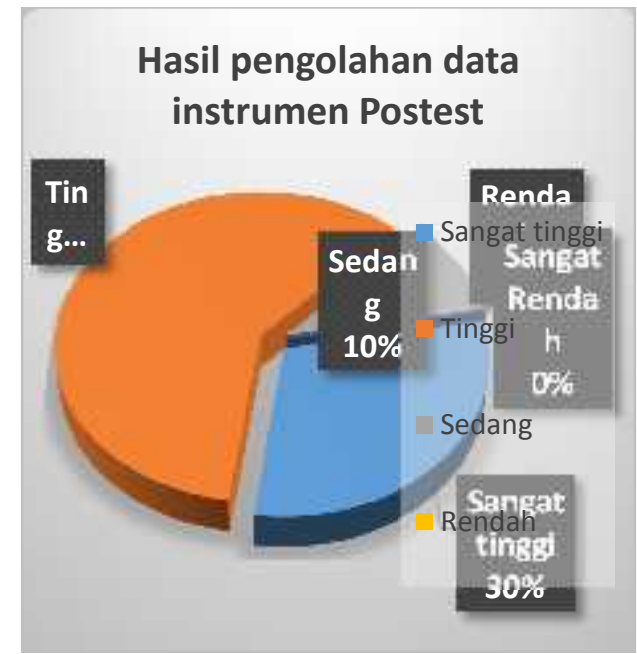

Setelah pelaksanaan orientasi teknis dan pembelajaran maka diperoleh hasil yang memuaskan. Hal ini ditunjukkan dari hasil postest yang menunjukkan bahwa 60\% anak memiliki kemampuan dan pemahaman yang tinggi dalam pembelajaran manajemen bencana alam banjir. Hanya $10 \%$ diantaranya yang masih pada kategori rendah. Untuk melihat perbandingan hasil pretes dan postest silahkan lihat grafik berikut:

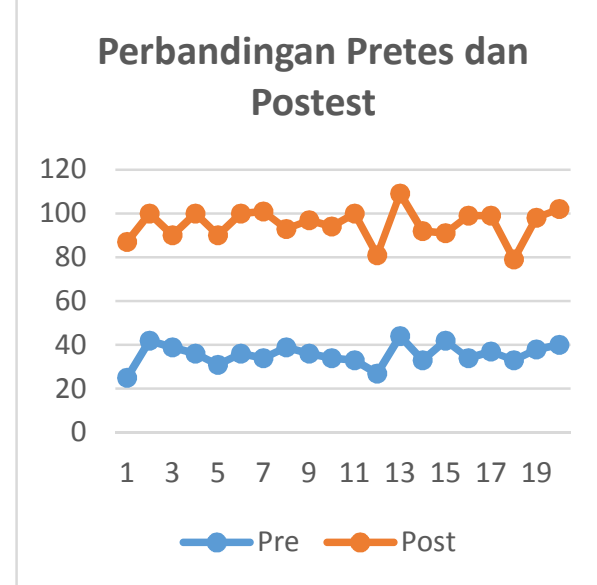

Dari hasil analisis data, maka disimpulkan bahwa terdapat perubahan dan peningkatan secara signifikan pemahaman anak sebelum dan sesudah dilaksanakannya penerapan model. Berdasarkan grafik di atas, semua indikator/materi pembelajaran meningkat dari sebelum pemberian perlakuan sampai dengan setelah diterapkannya pembelajaran manajemen bencana alam banjir.

2. TK Aisyiyah Bustanul Athfal 3 Bangkinang

Uji coba konseptual dilakukan pada TK Aisyiyah Bustanul Athfal 3 Bangkinang pada tanggal 23-25 Oktober 2017, berdasarkan pengolahan data instrument, maka diperoleh hasil:

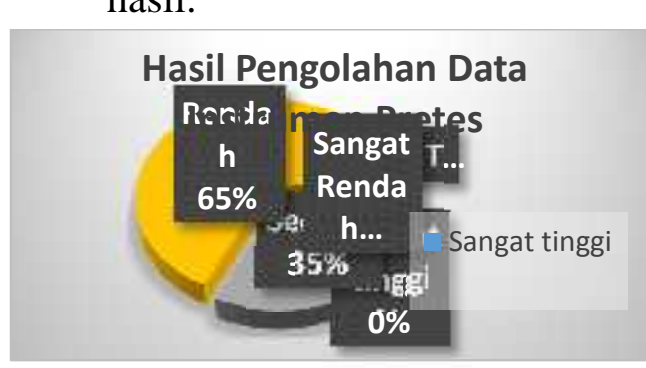


Sebelum dilaksanakan pembelajaran manajemen bencana alam banjir, anak usia 4-5 tahun diwawancarai atau diobservasi terlebih dahulu untuk mengukur tingkat pemahaman dan kompetensi anak usia 4-5 tahun dalam Pembelajaran manajemen bencana alam banjir. Adapun hasil yang diperoleh adalah $65 \%$ dari keseluruhan anak memiliki tingkat pemahaman mengenai bencana alam banjir adalah rendah. $35 \%$ lainnya berada pada kategori sedang, Berdasarkan hasil pretest dapat disimpulkan bahwa ratarata anak perlu mengikuti pembelajaran manajemen bencana alam banjir.

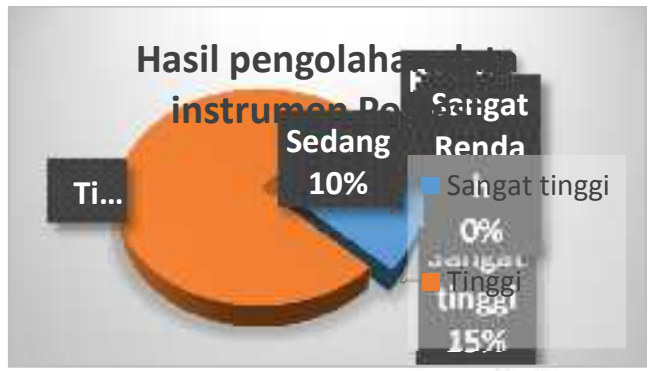

Setelah pelaksanaan pembelajaran maka diperoleh hasil yang memuaskan. Hal ini ditunjukkan dari hasil postest yang menunjukkan bahwa $75 \%$ anak memiliki kemampuan dan pemahaman yang tinggi dalam pembelajaran manajemen bencana alam banjir. $10 \%$ diantaranya yang masih pada kategori sedang,. Untuk melihat perbandingan hasil pretes dan postest silahkan lihat grafik berikut:

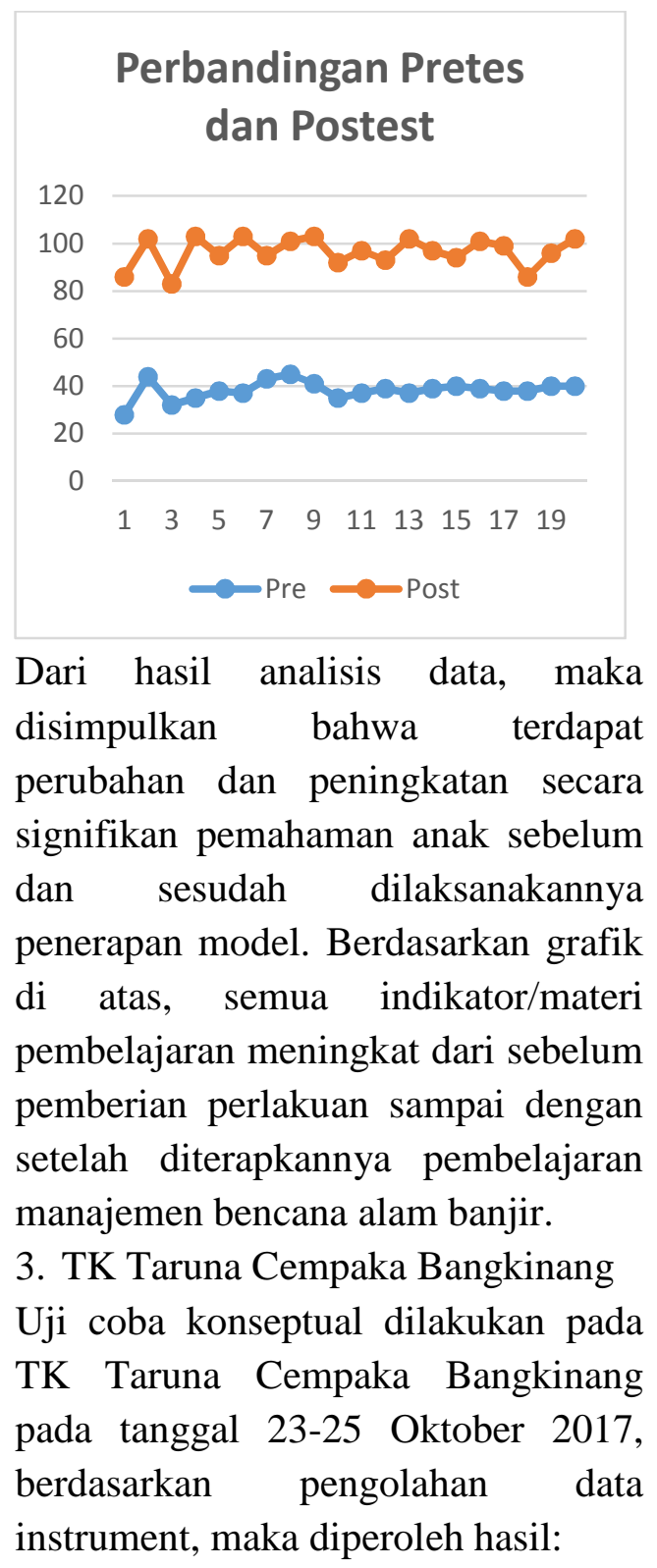




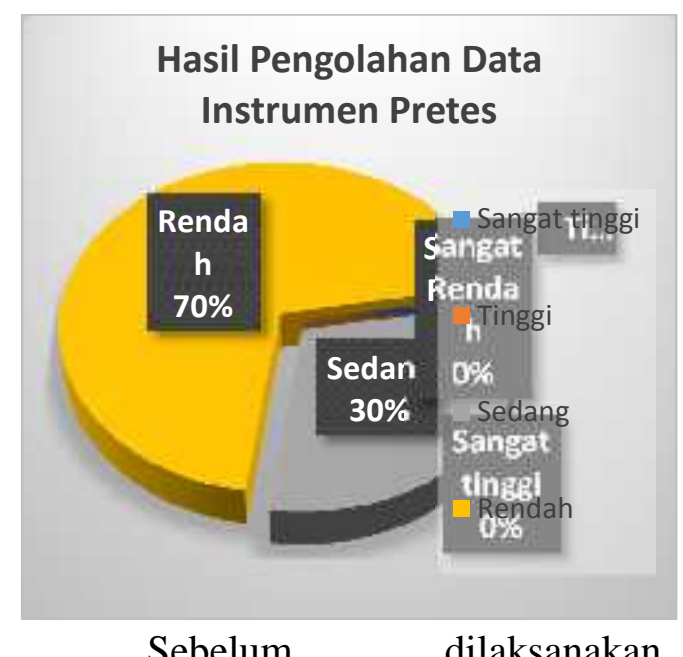

pembelajaran manajemen bencana alam banjir, anak usia 4-5 tahun diobservasi dan di wawancara terlebih dahulu untuk mengukur tingkat pemahaman anak usia 4-5 tahun mengenai manajemen bencana alam banjir. Adapun hasil yang diperoleh adalah $70 \%$ dari keseluruhan anak memiliki tingkat pemahaman mengenai bencana alam banjir adalah rendah. $30 \%$ lainnya berada pada kategori sedang, dan tidak anak yang berada pada kategori tinggi dan sangat tinggi.

Berdasarkan hasil pretest dapat disimpulkan bahwa rata-rata anak perlu mengikuti pembelajaran manajemen bencana alam banjir.

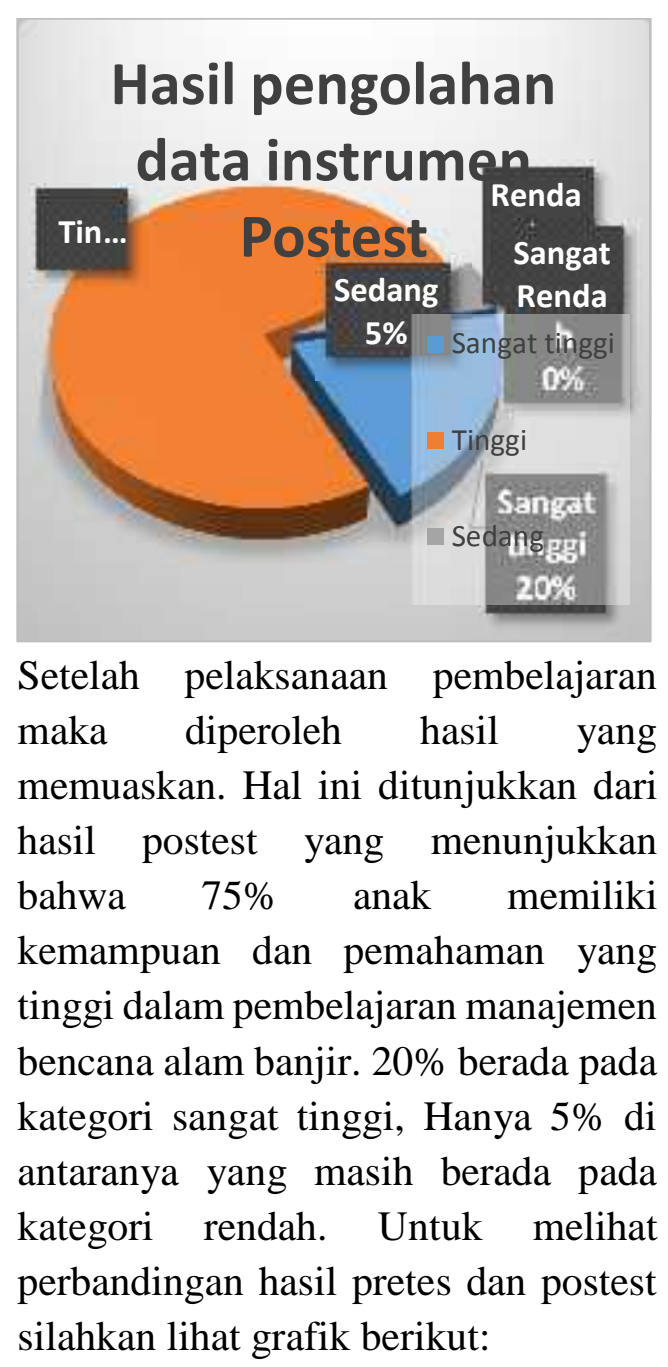

silahkan lihat grafik berikut: 


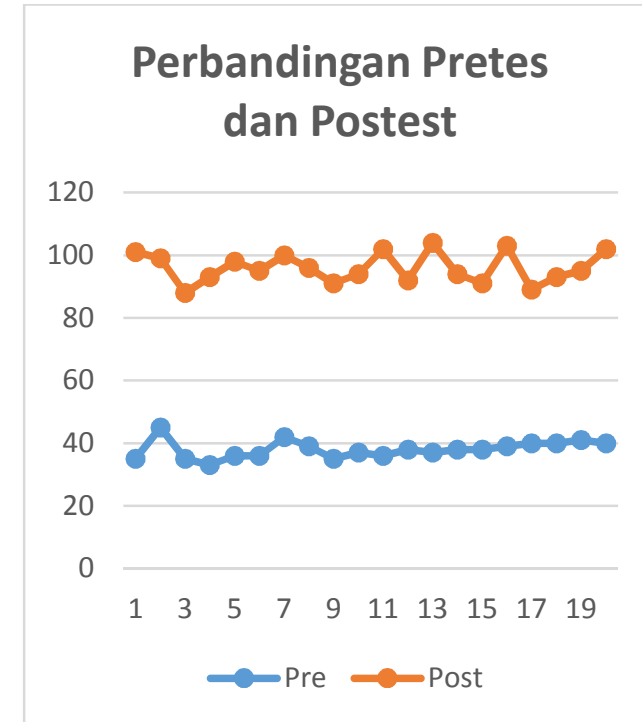

Dari hasil analisis data, maka disimpulkan bahwa terdapat perubahan dan peningkatan secara signifikan pemahaman anak sebelum dan sesudah dilaksanakannya penerapan model. Berdasarkan grafik di atas, semua indikator/materi pembelajaran meningkat dari sebelum pemberian perlakuan sampai dengan setelah diterapkannya pembelajaran manajemen bencana alam banjir.

\section{KESIMPULAN}

Simpulan hasil pengembangan model pembelajaran manajemen bencana alam banjir untuk anak usia 45 tahun adalah sebagai berikut:

1. Hasil Uji konseptual dan Uji Operasional model teruji bahwa model pembelajaran manajemen bencana alam banjir untuk anak usi 4-5 tahun layak untuk di aplikasikan dan dikembangkan.
2. Naskah yang dihasilkan dalam pengembangan model antara lain: a) Model pembelajaran manajemen bencana alam banjir untuk anak usia 4-5 tahun, b) Panduan Rancangan Pembelajaran manajemen bencana alam banjir, c) Panduan penggunaan media Pembelajaran manajemen bencana alam untuk anak usia 4-5 tahun, dan d) buku cerita dan lembar kerja anak.

3. Hasil validasi naskah Model pembelajaran manajemen bencana alam banjir untuk anak usia 4-5 tahun, Panduan Rancangan Model pembelajaran manajemen bencana alam banjir untuk anak usia 4-5 tahun, Panduan Penilaian Model pembelajaran manajemen bencana alam banjir untuk anak usia 4-5 tahun, dan buku cerita dan lembar kerja anak.

4. Hasil ujicoba penyelenggaraan Model pembelajaran manajemen bencana alam banjir untuk anak usia 4-5 tahun dapat dilihat pada kemampuan Guru untuk: a) menyusun perencanaan Pembelajaran manajemen bencana alam untuk anak usia 4-5 tahun, b) melaksanakan Pembelajaran manajemen bencana alam untuk anak usia 4-5 tahun, dan c) menilai tingkat percapaian peserta didik. 
DAFTAR PUSTAKA

[1] Agus Maryono, Menangani Banjir, Kekeringan, dan Lingkungan. Gadjah Mada University Press: 2014.

[2] Chaeroni, Wahyu Hendriyono, Widjo Kongko 2013. Pemodelan Tsunami dan Pembuatan Peta Rendaman untuk Keperluan Mitigasi di Teluk Jurnal Penanggulangan Bencana Volume 4 Nomor 2.

[3] Daryanto dan Agung Suprihatin, Pengantar Lingkungan Hidup, Yogyakarta, Gava Media: 2013.

[4] Dodge, Diane Trister. Creative Curriculum. Washington DC: Teaching Strategies Inc, 2002.

[5] Ibnu Rusydy. Melek Bencana. www.Ibnurusydy.com, diakses 8 Februari, 2016.

[6] Josef Tanusaputra, Bertahan Hidup di negeri Bencana, Jakarta, Elex Media Komputindo: 2015

[7] Mochamad Chazienul Ulum. 2013. Governance dan Capacity Building dalam Manajemen Bencana Banjir di Indonesia. Jurnal Penanggulangan Bencana Volume 4 Nomor 2.

[8] Nurjannah,dkk, Manajemen Bencana, Bandung, Alfa Beta: 2012.

[9] Sriwahyuni, S., \& Efastri, S. M. (2017). PENDAMPINGAN PEMBUATAN ALAT
PERMAINAN EDUKATIF DARI POTENSI SUMBER DAYA ALAM. Dinamisia: Jurnal Pengabdian Kepada Masyarakat, 1(1), 5-9.

[10] Sudibyakto, Manajemen Bencana di Indonesia Kemana?, Yogyakarta, Gadjah Mada University Press: 2011. 